\title{
Enhancing Flower Stalk Emergence in Phalaenopsis by Red Light Supplementation
}

\author{
Chun Hsien Lu1, Yo Ching Liu², Yuan Ting Hsu², Heng Long Wang1,2*, Jeng Der Chung3 \\ ${ }^{1}$ Institute of Biotechnology, National University of Kaohsiung, Taiwan \\ ${ }^{2}$ Department of Life Sciences, National University of Kaohsiung, Taiwan \\ ${ }^{3}$ Division of Silviculture, Taiwan Forestry Research Institute, Taiwan

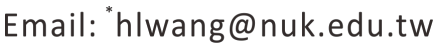

Received 20 February 2016; accepted 25 March 2016; published 29 March 2016

Copyright (C) 2016 by authors and Scientific Research Publishing Inc.

This work is licensed under the Creative Commons Attribution International License (CC BY).

http://creativecommons.org/licenses/by/4.0/

(c) (i) Open Access

\section{Abstract}

A key step in regulating the flowering of Phalaenopsis is to control the emergence of the flower stalk or spiking. Light quality is an important factor to regulate plant reproduction. We used either red or blue light emitting diodes (LEDs) to substitute for $10 \%$ photosynthetic photon flux emitted by white fluorescent tubes as the control (WC) at approximately $70 \mu \mathrm{mole} \cdot \mathrm{m}^{-2} \cdot \mathrm{s}^{-1}$ to examine the effects of enhanced red (WR) or blue (WB) light on spiking and the dawn-to-dusk fluctuations in the photosynthetic pigments and carbohydrates of Phalaenopsis aphrodite, which were grown in $7.5 \mathrm{~cm}$ diameter pots for six weeks. WR treatment significantly elevated the ratio of red to far-red light and the level of phytochrome photostationary state in concurrence with an increase in the spiking ratio and length, but had little effect on the concentrations of chlorophyll a and chlorophyll $b$ in the leaf, levels of soluble sugars such as glucose, fructose, sucrose, and insoluble starch in the leaf and shortened stem, the locus of spiking, when compared to the other two treatments. Evidently, the spiking of Phalaenopsis is improved by dependent on the relative amount of active phytochrome expressed in the photostationary state.

\section{Keywords}

Carbohydrate, Light-Emitting Diodes, Phalaenopsis, Phytochrome, Pigment

\section{Introduction}

Phalaenopsis orchids are popular and valuable potted ornamental plants worldwide for their beautiful and longlasting flowers that have a variety of shapes, sizes, and colors. Flowering time must be precisely scheduled to

\footnotetext{
${ }^{*}$ Corresponding author.
}

How to cite this paper: Lu, C.H., Liu, Y.C., Hsu, Y.T., Wang, H.L. and Chung, J.D. (2016) Enhancing Flower Stalk Emergence in Phalaenopsis by Red Light Supplementation. American Journal of Plant Sciences, 7, 639-648. 
meet market demands. One of the key steps in regulating Phalaenopsis flowering is to control the emergence of the flower stalk or spiking.

Phalaenopsis is a monopodial orchid with leaves alternating on each side of the plant and the bases of the leaves are connected to a shortened stem. One or 2 dormant flower stalk bud(s) emerges from the stem at the base of the third or fifth leaves that are numbered basipetally from the aerial portion of the plant [1].

Light is an important environmental condition for plant reproductive development. It is commonly recognized that light quantity has a close relationship with photosynthetic performance. The photosynthetic products, sugars, act as signals to control the reproductive development of plants [2]. In Phalaenopsis, many authors emphasized that sucrose concentration in the source leaf was correlated with the breaking of dormant flower stalk buds [3][7]; however, a conflicting observation has also been identified [8]-[10]. Although the leaf is the site of light signal perception, it is reasonable to speculate that the signal in the stem of Phalaenopsis is involved more directly to spike development than in the leaf because the flower stalk bud is connected with the shortened stem. Nevertheless, little is known about the relationships between carbohydrates, especially sucrose levels in the stems and spiking of Phalaenopsis.

Light quality is an important factor that regulates plant reproduction [11]. In response to low red/far-red (R/FR) ratio, flowering was accelerated in Arabidopsis [12], but was delayed in soybean [13]. Flower bud formation of Petunia was achieved with FR light treatment but inhibited by red light treatment [14]. A red light supplement at the crown delays flower bud induction and reduces flowering percentage in strawberry [15]. Blue light promoted flowering of Chenopodium rubrum but its effect was counteracted by red light [16]. Clearly, the aforementioned results manifested the effect of light quality on flowering varied among different plant species.

In fact, the effect of light quality upon photosynthetic pigments such as chlorophyll a (Chl a), chlorophyll b (Chl b), and/or carotenoids (Car) contents was also species dependent. For example, the pigment content in Atractylodes macrocephala [17], lettuce [18], and Petunia [14] was not affected but in Marigolds and Salvia [19], tomato [20], cucumber [21], or poinsettia [22] was significantly affected by light quality. Furthermore, in poinsettia, blue light increased $\mathrm{Chl}$ a content and promoted flowering but red light increased the contents of Chl $\mathrm{b}$ and delayed flowering [22]. In Arabidopsis, Chl b deficient mutants exhibit late flowering, whereas transgenic plant overproduces Chl b earlier flowering than the wild type [23]. However, there was not any correlation between chlorophyll content and flower bud formation in Petunia [14]. Different to the aforementioned plants, Phalaenopsis is an epiphytic orchid with thick, succulent leaves and exhibits a crassulacean acid metabolism (CAM) [5] [8] [9] [24]-[26]. The main objectives of this study are the impact of light quality on changes of dawn-to-dusk of photosynthetic pigment and carbohydrate concentrations in the leaf, the carbohydrates in the stem, and the nexus between spiking of Phalaenopsis.

Light-emitting diodes (LEDs) are a promising electric light source and have been used for different light regimes to demonstrate the effect of light quality on plant growth and development. Nevertheless, many studies have used LEDs as the sole light source despite of the quality of single wavelength or multiple wavelengths mixed in different ratios [13] [18] [27]. Brazaityte et al. [28] suggested that artificial lighting with too narrow a spectrum was not spectrally optimal for normal plant growth. Furthermore, in a natural environment, it is in conceivable that plants may be supplied with light having a narrow spectrum. Massa et al. [29] commented that broadening the spectrum could achieve better productivity and suggested that LEDs could be used to supplement sunlight or other types of lighting. Hence, in this study, we used white fluorescence tubes as a control treatment and $10 \%$ of the control photosynthetic photon flux (PPF) was replaced with red or blue LEDs as light quality treatments at the same irradiance conditions (approximately $70 \mu \mathrm{mole} \cdot \mathrm{m}^{-2} \cdot \mathrm{s}^{-1} \mathrm{PPF}$ ).

\section{Materials and Methods}

\subsection{Plant Material and Culture Conditions}

Phalaenopsis aphrodite subsp. formosana plants with 5 leaves were purchased from the Wusulin Farm of the Taiwan Sugar Corp., Tainan County, southern Taiwan $\left(23^{\circ} 34^{\prime} \mathrm{N}, 120^{\circ} 38^{\prime} \mathrm{E}\right)$, and grown in transparent plastic pots (7.5 cm diameter) filled with sphagnum moss in a computer controlled heating-ventilation system by forcing air through a diesel oil-burning heater to maintain the greenhouse at $28.0^{\circ} \mathrm{C} \pm 1.2^{\circ} \mathrm{C}$. Additionally, the plants were placed under a natural photoperiod without supplying any artificial light for 1 month. The average irradiance on the planting bench was maximum $150 \mu$ mole $\cdot \mathrm{m}^{-2} \cdot \mathrm{s}^{-1}$ PPF at noon on a fine day and measured by LI-250radiometer (Li-Cor, Lincoln, NE, USA). 
Six plants were transferred to a growth chamber (ST3-1, SAINT TIEN, Kaohsiung, Taiwan) for each light condition for 6 weeks. Pots were randomly rearranged every week to minimize any effect of edge or position with each treatment. The day and night temperature was set at $28.0 \pm 0.5$ and $20.0^{\circ} \mathrm{C} \pm 0.5^{\circ} \mathrm{C}$, respectively. The relative humidity was maintained at $70 \% \pm 5 \%$. Plants were irrigated once a week, alternating between HYPONEX No.1 (N:P:K, 7:6:19) and HYPONEX No.5 (N:P:K) (Hyponex, Marysville, OH, USA) water- soluble fertilizer $(1.0 \mathrm{~g} / \mathrm{L})$ at approximately $1.149 \mathrm{mS} / \mathrm{cm}$ and $397.5 \mu \mathrm{S} / \mathrm{cm}$, respectively, as measured by an electric conductivity meter (3250, JENCO, CA, USA).

\subsection{Light Treatments}

Cool white fluorescence tubes (F20T12, GE, NY, USA) were used as the main light source and were placed vertically. Two LED panels $(200 \times 200 \mathrm{~mm}$, HiPoint, Kaohsiung, Taiwan) of red (peak at $660 \pm 10 \mathrm{~nm})$ or blue (peak at $450 \pm 10 \mathrm{~nm}$ ) were placed horizontally approximately $25 \mathrm{~cm}$ above the plant canopy inside the growth chamber to achieve approximately $10 \%$ light substitution. The 3 experimental plots were named control (WC), blue enhanced (WB), and red enhanced (WR). All treatments were maintained with a 14 h photoperiod (06:0020:00 light/20:00-06:00 dark) and approximately $70 \mu$ mole $\cdot \mathrm{m}^{-2} \cdot \mathrm{s}^{-1} \mathrm{PPF}$ above the plant canopy (Table 1 ). Light spectral distribution was scanned from 380 to $780 \mathrm{~nm}$ at 1-nm intervals using a spectroradiometer (LCS-100, Isuzu Optics, Hsinchu, Taiwan) and the spectrum was recorded at the top of the plant canopy (Figure 1). The contribution of blue $(400-500 \mathrm{~nm})$, green $(500-600 \mathrm{~nm})$, red $(600-700 \mathrm{~nm})$, far-red $(700-780 \mathrm{~nm})$ and total PPF were determined by bandwidth integration. From the spectroradiometer data for each light treatment, the red to far-red ratio (R/FR) was calculated as (integrated photon flux density at 655 - $665 \mathrm{~nm}$ ) (integrated photon flux density at $725-735 \mathrm{~nm}^{-1}$ ) [30], and the value of phytochrome photostationary state (PSS) was calculated according to the following equation described by Sager et al. [31]:
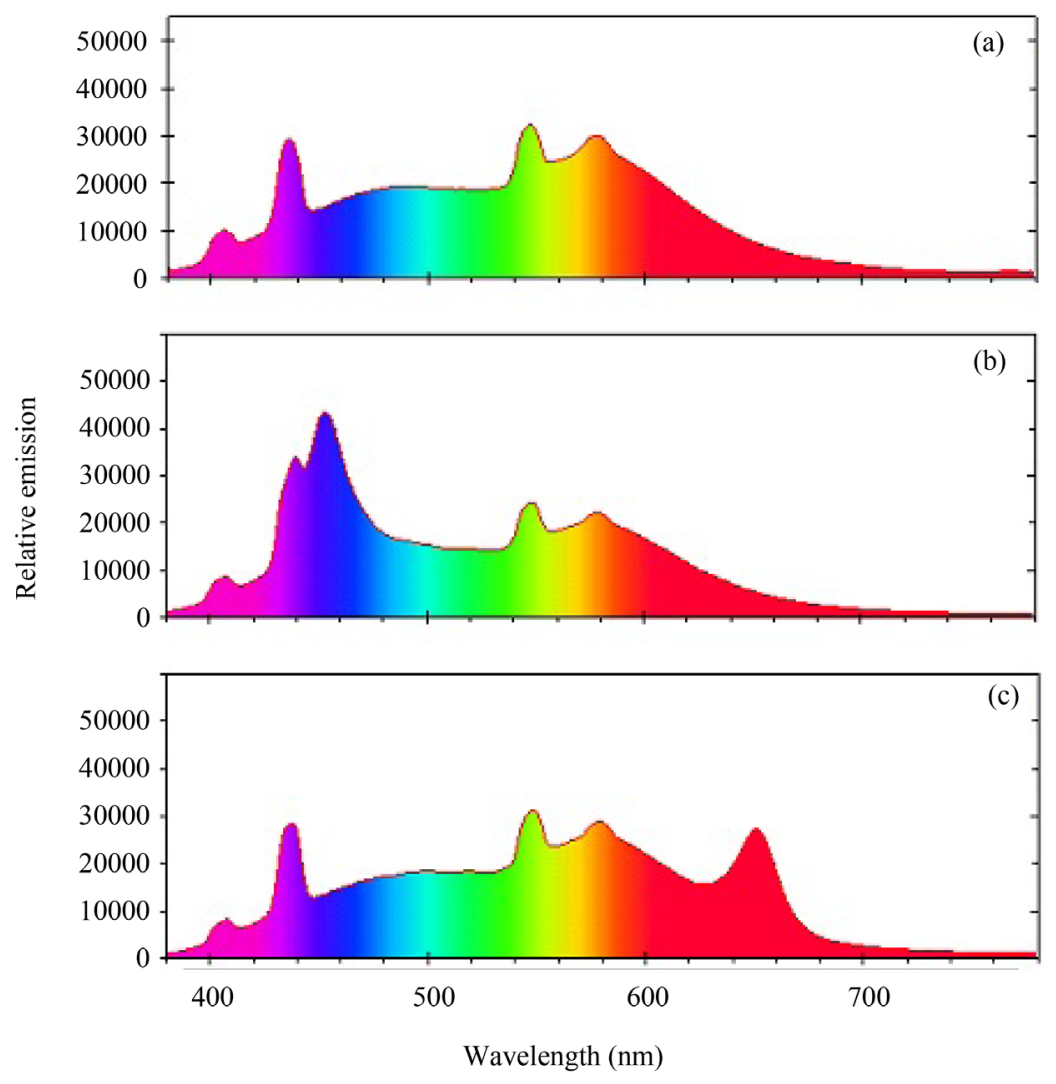

Figure 1. Spectral distribution of (a) the cool white fluorescence tubes control (WC), (b) white light with supplemental blue light (WB), and (c) white light with supplemental red light (WR). 
Table 1. Spectral quality of 3 light sources, cool white fluorescence light (WC), white light with supplemental blue light (WB) and white light with supplemental red light (WR). The value in parentheses represents the percentage over photosynthetic photon flux (PPF). Spectra were recorded and averaged at four locations at the top of plant canopy with a spectroradiometer. Different letters show significant difference among three treatments $(\mathrm{P}<0.05)$. ${ }^{\mathrm{x}}$ Total photon flux of the background white fluorescent lamp and supplemental light-emitting diodes. ${ }^{\mathrm{y} C a l c u l a t e d}$ according to Kurata et al. (2007). ${ }^{\mathrm{z}} \mathrm{Cal}-$ culated according to Sanger et al. (1988).

\begin{tabular}{cccc}
\hline Parameter & \multicolumn{3}{c}{ Treatments } \\
\cline { 2 - 4 } & WC & WB & WR \\
\hline Photon flux $\left(\mu \mathrm{mole} \cdot \mathrm{m}^{-2} \cdot \mathrm{s}^{-1}\right)^{\mathrm{x}}$ & & & $67.3 \pm 0.2(100 \%)$ \\
PPF $(400-700 \mathrm{~nm})$ & $71.9 \pm 1.3(100 \%)$ & $69.5 \pm 0.4(100 \%)$ & $17.0 \pm 0.1(25.3 \%)$ \\
Blue $(400-500 \mathrm{~nm})$ & $20.5 \pm 0.1(28.5 \%)$ & $27.8 \pm 0.3(40.0 \%)$ & $30.0 \pm 0.1(44.6 \%)$ \\
Green $(500-600 \mathrm{~nm})$ & $36.4 \pm 0.8(50.6 \%)$ & $29.6 \pm 0.4(42.6 \%)$ & $20.3 \pm 0.2(30.1 \%)$ \\
Red $(600-700 \mathrm{~nm})$ & $15.0 \pm 0.5(20.9 \%)$ & $12.1 \pm 0.2(17.4 \%)$ & $1.75 \pm 0.03$ \\
Far-red $(700-780 \mathrm{~nm})$ & $1.92 \pm 0.09$ & $1.62 \pm 0.04$ & $12.19^{\mathrm{a}} \pm 0.97$ \\
R:FR & $4.03^{\mathrm{b}} \pm 0.04$ & $3.63^{\mathrm{c}} \pm 0.04$ & $0.842^{\mathrm{a}} \pm 0.004$ \\
\hline PSS $^{\mathrm{z}}$ & $0.811^{\mathrm{b}} \pm 0.002$ & $0.785^{\mathrm{c}} \pm 0.008$ & \\
\hline
\end{tabular}

$$
P S S=\left(\sum_{380}^{780} N_{\lambda} \sigma_{\gamma_{\lambda}}\right) /\left(\sum_{380}^{780} N_{\lambda} \sigma_{\gamma_{\lambda}}+\sum_{380}^{780} N_{\lambda} \sigma_{f_{\gamma \lambda}}\right)
$$

Here, $N$ and $\sigma$ denote irradiance and the photochemical cross-section area, respectively, at each wavelength $(\lambda)$ from 380 - $780 \mathrm{~nm}$ against the relative absorption for Pr and Pfr forms of phytochrome. The range of wavelength was not the same as that used by Sager et al. [31] from 300 - $800 \mathrm{~nm}$ due to the limitation of spectroradiometer used.

\subsection{Determination of Spiking Characteristics}

Spiking was defined as the appearance of a flower stalk equal or larger than $0.5 \mathrm{~cm}$ long [9]. The spiking ratio represented the ratio for all plants from 5 batches of experiments, with 6 plants for each batch and each treatment. The spike length was measured from the base of the flower stalk at the junction between the base of the leaves and short internode stem to the apex of the flower stalk [9].

\subsection{Sampling Procedure}

The leaves were numbered basipetally, and the second leaf (approximately $25 \mathrm{~cm}^{2}$ ) was approximately two-fold the size of the first leaf. Leaf discs (approximately $0.28 \mathrm{~cm}^{2}$ ) from the second leaf were cut from the middle and approximately $0.5 \mathrm{~cm}$ away from the main vein of the second leaf with use of a cork borer [8]. After all leaves were completely removed, a knife was used to harvest the stem from the junction between the base of the flower stalk bud and the shortened stem, and removed the flower stalk. Three plant replicates were separately obtained at 06:00 (dawn) and 18:00 (dusk) for each treatment. The leaf discs and stems were rapidly weighed and frozen in liquid $\mathrm{N}_{2}$ for analysis.

\subsection{Determination of Photosynthetic Pigment Concentration}

The contents of Chl a, Chl b, and Car were determined according to the method described by Lichtenthaler [32]. In this method, fresh leaf discs (ca. $200 \mathrm{mg}$ ) were extracted in 80\% (v/v) acetone. Extracts were centrifuged at $10,000 \times \mathrm{g}$ for $5 \mathrm{~min}$. The absorbance of supernatant was measured at 663.2, 646.8, and $470 \mathrm{~nm}$ with a spectrophotometer (DU640, Beckman Coulter, USA).

$\mathrm{Chl} \mathrm{a}, \mathrm{Chl} \mathrm{b}$, and Car contents $(\mu \mathrm{g} / \mathrm{g} \mathrm{FW})$ were calculated using the following formulas:

Chl a $=\left(12.25 \mathrm{~A}_{663.2}-2.79 \mathrm{~A}_{646.8}\right) \times \mathrm{F}$;

Chl $\mathrm{b}=\left(21.21 \mathrm{~A}_{646.8}-5.1 \mathrm{~A}_{663.2}\right) \times \mathrm{F}$; and 
Car $=\left[\left(1000 \mathrm{~A}_{470}-1.8 \mathrm{Chl} \mathrm{a}-85.02 \mathrm{Chl} \mathrm{b}\right) / 198\right] \times \mathrm{F}$.

where $\mathrm{F}=$ volume of supernatant $(\mathrm{mL}) / \mathrm{sample} \mathrm{FW}(\mathrm{g})$.

\subsection{Maintaining the Integrity of the Specifications}

Leaf discs and stems were separately homogenized and sugars were extracted with $80 \%$ (v/v) ethanol at $80^{\circ} \mathrm{C}$ to determine the soluble sugar concentrations. The supernatant was evaporated in an $\mathrm{N}_{2}$ gas stream and dissolved in deionized water. Sugars were separated by anion exchange chromatography (BioLC, Dionex) with CarboPac PA10column [8]. Sediment was digested with a mixture of pullulanase and amyloglucosidase, and the amount of liberated glucose was estimated by a glucose oxidase and peroxidase method to determine starch content [8].

\subsection{Statistical Analysis}

Data are indicated as mean \pm SE. The data were subjected to one-way ANOVA and the differences between means were measured at the 5\% probability level using Fisher's protected least significant difference (LSD) test (CoHort Software, Monterey, CA).

\section{Results}

\subsection{Light Source Characteristics}

The control (WC) light sources had the spectrum distribution (Figure 1(a)) defined as the percentage over PPF of $28.5 \%$ at $400-500 \mathrm{~nm}, 50.6 \%$ at $500-600 \mathrm{~nm}$, and $20.9 \%$ at $600-700 \mathrm{~nm}$ (Table 1). The blue enhanced (WB) had an additional supply of $11.5 \%$ of the total PPF in the blue spectrum (400 - $500 \mathrm{~nm}$ ) compared to the control. Thus, it changed the spectrum distribution (Figure 1(b)) to $40.0 \%$ of the PPF at $400-500 \mathrm{~nm}, 42.6 \%$ at $500-600 \mathrm{~nm}$, and $17.4 \%$ at $600-700 \mathrm{~nm}$ (Table 1). The red enhanced (WR) had an additional supply of 9.2\% of the total PPF in the red spectrum (600 - $700 \mathrm{~nm}$ ) compared to the control and resulting in a spectrum distribution (Figure 1(c)) of $25.3 \%$ of the PPF at $400-500 \mathrm{~nm}, 44.6 \%$ at $500-600 \mathrm{~nm}$, and $30.1 \%$ at $600-700 \mathrm{~nm}$ (Table 1). Although the mean total PPF of WR was $67.3 \mu$ mole $\cdot \mathrm{m}^{-2} \cdot \mathrm{s}^{-1}$ slightly lower than that of 69.5 and 71.9 $\mu$ mole $\cdot \mathrm{m}^{-2} \cdot \mathrm{s}^{-1}$ in WB and WC, respectively, the value of PSS in WR was 0.842 , which was significantly higher than for 0.785 and 0.811 in WB and WC, respectively. Meanwhile, the ratio of red to far-red in WR was 12.19, significantly higher than for 3.63 and 4.03 in WB and WC, respectively (Table 1). These results clearly show that a slight increase in red supplement greatly elevated the level of PSS and the R/FR ratio in WR compared to WB and WC.

\subsection{Spike Development}

The mean spiking ratio was $78 \%$ in WR under almost equivalent PPF levels, which was much higher than $14 \%$ and $2 \%$ of WB and WC, respectively (Table 2). The mean spike length was $3.6 \mathrm{~cm}$ in WR, which was longer than the just-emerged spiking of both WB and WC (Table 2). Evidently, a 10\% of red light supplementation indeed enhanced spike development, and WB and WC could not show such enhancement.

\subsection{Photosynthetic Pigments}

The concentrations of $\mathrm{Chl} \mathrm{a,} \mathrm{Chl} \mathrm{b,} \mathrm{Chl} \mathrm{a} \mathrm{+} \mathrm{Chl} \mathrm{b,} \mathrm{and} \mathrm{the} \mathrm{ratio} \mathrm{of} \mathrm{Chl} \mathrm{a/Chl} \mathrm{b} \mathrm{did} \mathrm{not} \mathrm{show} \mathrm{differences} \mathrm{among} 3$

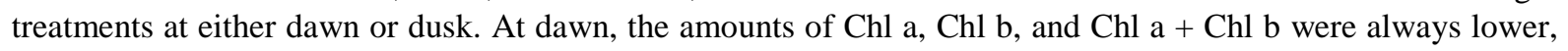
but the mean ratio of $\mathrm{Chl}$ a to $\mathrm{Chl} b$ were higher than at dusk in all treatments (Table 3).

Table 2. Influence of light quality on the spike development of $P$. aphrodite exposed to WC, WB and WR for 6 weeks. The mean spiking ratio and length are obtained from 5 batch experiments, with 6 individual plants each. Different letters show significant difference among 3 treatments $(\mathrm{P}<0.05)$.

\begin{tabular}{cccc}
\hline & WC & WB & WR \\
\hline Spiking ratio $(\%)$ & $2^{\mathrm{b}} \pm 4$ & $14^{\mathrm{b}} \pm 18$ & $78^{\mathrm{a}} \pm 26$ \\
Spiking length $(\mathrm{cm})$ & $0.5^{\mathrm{b}} \pm 0.1$ & $0.5^{\mathrm{b}} \pm 0.2$ & $3.6^{\mathrm{a}} \pm 1.6$ \\
\hline
\end{tabular}


The concentrations of carotenoids at dawn were all lower than at dusk and did not exhibit distinct differences among 3 treatments at dusk. However, at dawn, the lowest level was shown in the WR, resulted in the mean magnitude of dusk-to-dawn oscillation was $46 \mu \mathrm{g} / \mathrm{g} \mathrm{FW}$, which was slightly higher than 34 and $40 \mu \mathrm{g} / \mathrm{g}$ FW in WC and WB, respectively (Table 3).

\subsection{Carbohydrates}

Table 4 compares the influence of light quality on the dawn and dusk concentration of carbohydrate of the second leaf and stem. In the leaf, no differences in glucose and fructose contents and dawn-to-dusk fluctuations among the three treatments. Sucrose was the major component of free soluble sugars, accounting for 95\%, 94\%, and $94 \%$ at dawn, and $76 \%, 80 \%$, and $85 \%$ at dusk of total sugars (the sum of glucose, fructose, and sucrose) of WC, WB, and WR treatments, respectively. However, a slight dawn-to-dusk fluctuation of sucrose concentration in WC and WR appeared higher at dawn than at dusk, but this fluctuation did not occur in WB. By contrast, the starch showed a significant dawn-to-dusk deposition in all three treatments and its amplitude was 7.0, 6.6, and $8.1 \mathrm{mg} / \mathrm{g}$ FW in WC, WB, and WR, respectively.

Table 3. Influence of light quality on the dawn and dusk concentration of photosynthetic pigments of the second leaf from $P$. aphrodite exposed to WC, WB, and WR for 6 weeks. All values are mean \pm SE of the 3 individual plants. Different letters show statistically significant differences among the 3 treatments at the same sampling time $(\mathrm{P}<0.05)$. The asterisks indicate significant differences between dawn and dusk in samples under the same treatment $(\mathrm{P}<0.05)$.

\begin{tabular}{|c|c|c|c|c|c|c|}
\hline & \multicolumn{3}{|c|}{ Dawn } & \multicolumn{3}{|c|}{ Dusk } \\
\hline & WC & WB & WR & WC & WB & WR \\
\hline $\begin{array}{l}\text { Chlorophyll a } \\
\text { ( } \mu \mathrm{g} / \mathrm{g} \text { FW) }\end{array}$ & $167^{\mathrm{a}} \pm 2$ & $141^{\mathrm{a}} \pm 13$ & $147^{\mathrm{a}} \pm 7$ & $194^{\mathrm{a}, *} \pm 9$ & $194^{\mathrm{a}, *} \pm 8$ & $194^{\mathrm{a}, *} \pm 16$ \\
\hline $\begin{array}{l}\text { Chlorophyll b } \\
\text { ( } \mu \mathrm{g} / \mathrm{g} \mathrm{FW})\end{array}$ & $51^{\mathrm{a}} \pm 2$ & $42^{\mathrm{a}} \pm 4$ & $51^{\mathrm{a}} \pm 6$ & $86^{\mathrm{a}, *} \pm 7$ & $88^{\mathrm{a}, *} \pm 5$ & $86^{\mathrm{a}, *} \pm 9$ \\
\hline $\begin{array}{l}\text { Total chlorophyll } \\
\qquad(\mu \mathrm{g} / \mathrm{g} \mathrm{FW})\end{array}$ & $217^{\mathrm{a}} \pm 5$ & $183^{\mathrm{a}} \pm 17$ & $198^{\mathrm{a}} \pm 9$ & $281^{\mathrm{a}, *} \pm 16$ & $282^{\mathrm{a},{ }^{*}} \pm 13$ & $279^{\mathrm{a}, *} \pm 24$ \\
\hline Chl a/Chl b & $3.3^{\mathrm{a}, *} \pm 0.1$ & $3.4^{\mathrm{a}, *} \pm 0.1$ & $2.9^{\mathrm{a}} \pm 0.3$ & $2.3^{\mathrm{a}} \pm 0.1$ & $2.2^{\mathrm{a}} \pm 0.0^{\mathrm{a}}$ & $2.3^{\mathrm{a}} \pm 0.0$ \\
\hline $\begin{array}{l}\text { Carotenoids } \\
(\mu \mathrm{g} / \mathrm{g} \mathrm{FW})\end{array}$ & $24^{\mathrm{a}} \pm 1$ & $19^{\mathrm{ab}} \pm 3$ & $17^{\mathrm{b}} \pm 2$ & $58^{\mathrm{a}, *} \pm 1$ & $59^{\mathrm{a}, *} \pm 5$ & $63^{\mathrm{a}, *} \pm 5$ \\
\hline
\end{tabular}

Table 4. The influence of light quality on the dawn and dusk concentration of carbohydrates of the second leaf and stem from $P$. aphrodite exposed to WC, WB, and WR for 6 weeks. All values are mean \pm SE of the 3 individual plants. Different letters show statistically significant differences among the 3 treatments at the same sampling time $(\mathrm{P}<0.05)$. The asterisks indicate significant differences between dawn and dusk in samples under the same treatment $(\mathrm{P}<0.05)$.

\begin{tabular}{|c|c|c|c|c|c|c|}
\hline \multirow{2}{*}{$\begin{array}{c}\text { Carbohydrate } \\
(\mu \mathrm{g} / \mathrm{g} \text { FW })\end{array}$} & \multicolumn{3}{|c|}{ Dawn } & \multicolumn{3}{|c|}{ Dusk } \\
\hline & WC & WB & WR & WC & WB & WR \\
\hline \multicolumn{7}{|l|}{ Leaf } \\
\hline Glucose & $0.09^{\mathrm{a}} \pm 0.01$ & $0.10^{\mathrm{a}} \pm 0.02$ & $0.12^{\mathrm{a}} \pm 0.03$ & $0.12^{\mathrm{a}} \pm 0.05$ & $0.25^{\mathrm{a}} \pm 0.16$ & $0.10^{\mathrm{a}} \pm 0.04$ \\
\hline Fructose & $0.05^{\mathrm{a}} \pm 0.01$ & $0.06^{\mathrm{a}} \pm 0.02$ & $0.12^{\mathrm{a}} \pm 0.05$ & $0.19^{\mathrm{a}} \pm 0.10$ & $0.45^{\mathrm{a}} \pm 0.28$ & $0.09^{\mathrm{a}} \pm 0.05$ \\
\hline Sucrose & $2.70^{\mathrm{a}, *} \pm 0.17$ & $2.52^{\mathrm{a}} \pm 0.37$ & $3.70^{\mathrm{a}, *} \pm 0.85$ & $1.01^{\mathrm{a}} \pm 0.06$ & $2.72^{\mathrm{a}} \pm 1.30$ & $1.08^{\mathrm{a}} \pm 0.11$ \\
\hline Starch & $1.32^{\mathrm{a}} \pm 0.10$ & $0.61^{\mathrm{c}} \pm 0.07$ & $0.98^{\mathrm{b}} \pm 0.07$ & $8.32^{\mathrm{a},{ }^{*}} \pm 1.33$ & $7.26^{\mathrm{a}, *} \pm 0.31$ & $9.09^{\mathrm{a},{ }^{*}} \pm 0.32$ \\
\hline \multicolumn{7}{|l|}{ Stem } \\
\hline Glucose & $0.65^{\mathrm{a}} \pm 0.19$ & $0.25^{\mathrm{a}} \pm 0.03$ & $0.61^{\mathrm{a}} \pm 0.16$ & $0.65^{\mathrm{a}} \pm 0.25$ & $1.25^{\mathrm{a}} \pm 0.57$ & $0.45^{\mathrm{a}} \pm 0.09$ \\
\hline Fructose & $0.36^{\mathrm{a}} \pm 0.11$ & $0.10^{\mathrm{a}} \pm 0.01$ & $0.37^{\mathrm{a}} \pm 0.10$ & $0.29^{b} \pm 0.05$ & $1.02^{\mathrm{a}, *} \pm 0.22$ & $0.55^{\mathrm{ab}} \pm 0.26$ \\
\hline Sucrose & $14.2^{\mathrm{a}} \pm 1.3$ & $17.1^{\mathrm{a}} \pm 1.9$ & $14.2^{\mathrm{a}} \pm 1.3$ & $15.0^{\mathrm{a}} \pm 2.6$ & $16.4^{\mathrm{a}} \pm 1.7$ & $13.4^{\mathrm{a}} \pm 1.6$ \\
\hline Starch & $6.28^{\mathrm{a}} \pm 2.07$ & $4.66^{\mathrm{a}} \pm 0.07$ & $5.37^{\mathrm{a}} \pm 1.13$ & $5.24^{\mathrm{a}} \pm 2.20$ & $6.30^{\mathrm{a}} \pm 1.75$ & $3.09^{\mathrm{a}} \pm 0.16$ \\
\hline
\end{tabular}


Compared with the leaf, the stem carbohydrate contents including glucose, fructose, sucrose, and starch were rather stable, except that fructose showed a slight difference at dusk. Sucrose was also a major component of free soluble sugars and accounted for 93\%, 98\%, and 94\% at dawn and 94\%, 88\%, and 95\% at dusk of total sugars in WC, WB, and WR, respectively. Moreover, the sucrose concentrations in the stem was about 5-, 7-, and 4-fold at dawn and 15-, 7-, and 13-fold at dusk higher than in the leaf in WC, WB, and WR, respectively.

\section{Discussion}

It is commonly recognized that the quantity of light energy correlates directly with photosynthetic performance. Although the magnitude of dawn-to-dusk starch biosynthesis in the leaf was slightly increased in WR, the contents of glucose, fructose, and sucrose in the leaf and stem, and starch in the stem did not show significant differences among the three treatments (Table 4). Hence, under the almost equivalent light quantity condition, the carbon pool metabolism of Phalaenopsis is not much affected by a $10 \%$ change in light quality with red or blue light supplementation.

Sucrose concentration was found to be higher in the leaf of Phalaenopsis under a spike-emergence state than a spike-inhibited state [3]-[7]. Tsai et al. [6] also demonstrated that sucrose concentration in the leaf was negatively related to the length of time to reach spiking. However, these studies all examined the new and fully expanded leaf. Leaves are the primary site of perception for light cues that are transmitted to the shoot apical meristem via the phloem to evoke the transition from vegetative growth to reproductive development [33]. In this study, the sucrose concentration in the stem was significantly higher than in the leaf; meanwhile, there was no difference in the 3 light treatments either in the second leaf or in the stem (Table 4). These results are concurrent with Liu et al. [9], which manifested the sucrose concentration in the stem was profoundly higher than in the different ages of leaves of Phalaenopsis, irrespective of spiking or not. Therefore, the relationship between spiking and sucrose concentration is seemingly not so tight in Phalaenopsis.

The effect of light quality upon photosynthetic pigment content, and the correlation between pigment change and developmental transition reported so far appeared to be rather complex. In this study, Chl a, Chl b, and Car all were degraded during nighttime and a 10\% red or blue LED supplementation did not greatly affect the contents of these pigments, even though the magnitudes of dusk-to-dawn fluctuation in Chl a/b ratio and Car content had slight changes among the three treatments (Table 3). Evidently, the spiking of Phalaenopsis induced by a $10 \%$ red LED supplementation is not mediated by the alternation of photosynthetic pigments.

The flowering of many Phalaenopsis cultivars was hastened when grown under the red shade net as compared to blue and black shade ones [34]. Recently, Dueck et al. [35] published that a high red:far red ratio via supplemental high pressure sodium resulting in a high PSS value can enhance flower bud break of two Phalaenopsis cultivars, Quincy and Red Stones, compared to the supplement of a combination of high pressure sodium and far-red LEDs with a low PSS value. In this study, likewise, a 10\% increase in red supplement significantly elevated the ratio of red to far-red light and the level of PSS (Table 1). Accordingly, the spiking development increased (Table 2). These results strongly highlight that the spike emergence of $P$. aphrodite closely depends on the relative amount of active phytochrome expressed as the photostationary state.

The light spectrum affects the hormone balance in plants [36]. Red light induces a great increase in the expression of a key gene for gibberellin (GA) biosynthesis in lettuce [37]. Although GAs affect flowering in a species-dependent manner, Ben-Tal and Erner [38] demonstrated that GAs were routinely used to promote flowering in many ornamental plants, such as Chrysanthemum, Hypericum, Gypsophilla, and Campanula. Similarly, GA content increased in the flowering shoots of Phalaenopsis under low temperature conditions when flowering development was promoted [39]. Applications of GA and cytokinin, such as benzyladenine (BA) simultaneously or BA alone promoted flowering of Phalaenopsis; however, BA treatment has the risk to develop abnormal inflorescence [40]. Phytochrome negatively controlled GA sensitivity and/or biosynthesis [41], and the level of R/FR ratio affected biosynthesis or distribution of other hormones, such as auxin, cytokinin, ethylene, and brassinosteroid [42]. Hence, mechanisms for the phytochrome-mediated spike emergence of Phalaenopsis via changing the type and/or concentrations of various phytohormones or other downstream mediators acting as a leaf-to-stem transported signal remain to be explored.

Temperature is a primary factor that affects the transition from a vegetative into a reproductive state in Phalaenopsis [43]. It should be mentioned that the temperature regime in this study was set at the spike-inducing condition as follows: warm day $\left(28^{\circ} \mathrm{C}\right)$ and cool night $\left(20^{\circ} \mathrm{C}\right)$, as in our previous study [8]. In our earlier study, 
plants with 7 leaves were grown in $10.5 \mathrm{~cm}$ diameter pots, the size of the second leaf was ca. $85 \mathrm{~cm}^{2}$, and the spike emergence was significant in 4 weeks [8]. In this study, however, under the same temperature conditions, no significant spiking occurred in the control (WC) plants (Table 2), which had 5 leaves and were grown in 7.5 $\mathrm{cm}$ diameter pots and the experimental leaf was only ca. $25 \mathrm{~cm}^{2}$ in size. These results are consistent with Paradiso and De Pascale [44] addressed that the time for spike emergence was strongly influenced by the plant size, and Blanchard et al. [45] reported that a longer cooling duration may be required for smaller Phalaenopsis plants.

For Phalaenopsis, it is a rather complex and time-consuming process from spike emergence to flowering. It takes about 4 - 5 months for $P$. aphrodite from spike emergence to the first floret appearance. Meanwhile, the culturing conditions in commercial production are different between spike induction and inflorescent development [44] [46]. In this study, we focused on the effects of light quality on spike emergence because breaking the dormancy of flower stalk/spike bud(s) was a key step to produce flowers in Phalaenopsis. Orchid growers induce spike emergence when the orchid is grown in a pot of $10.5 \mathrm{~cm}$ diameter. We examined the plants cultured in $7.5 \mathrm{~cm}$ diameter pot in this study because they were limited by the space of the growth chamber $(620 \times 520 \times$ $1300 \mathrm{~mm})$ and the size of LED panel $(200 \times 200 \mathrm{~mm})$. Nonetheless, there are some commercial markets for those grown in smaller pots. For Phalaenopsis breeders, it takes a long time to know the flower characteristics after hybridization. Therefore, accelerating the spike emergence can shorten the breeding time.

Overall, this study offers some potentially practical value for promoting spike development in Phalaenopsis by supplementing red light and opens up a new academic approach via the induction of PSS to control spiking in Phalaenopsis.

\section{Acknowledgements}

The authors would like to thank Professor Jong-Ching Su, Professor Fure-Chyi Chen and Doctor Yung-I Lee for helpful comments on drafting this manuscript. The authors sincerely thank HiPoint Co. (Taiwan) for lending the spectroradiometer (LCS-100; Isuzu Optics Co., Hsinchu, Taiwan) to scan light spectral distribution. This work was supported by the grant NSC 98-2313-B-390-001-MY3 from the National Science Council, Executive Yuan, Taiwan.

\section{References}

[1] Sakanishi, Y., Imanishi, H. and Ishida, G. (1980) Effect of Temperature on Growth and Flowering of Phalaenopsis amabilis. Bulletin of University of Osaka Prefecture, Series B, 32, 1-9.

[2] Rolland, F., Baena-Gonzalez, E. and Sheen, J. (2006) Sugar Sensing and Signaling in Plants: Conserved and Novel Mechanisms. Annual Review of Plant Biology, 57, 675-709. http://dx.doi.org/10.1146/annurev.arplant.57.032905.105441

[3] Konow, E.A. and Wang, Y.T. (2001) Irradiance levels Affect in Vitro and Greenhouse Growth, Flowering, and Photosynthetic Behavior of a Hybrid Phalaenopsis Orchid. Journal of the American Society for Horticultural Science, 126, 531-536.

[4] Kataoka, K., Sumitomo, K., Fudano, T. and Kawase, K. (2004) Changes in Sugar Content of Phalaenopsis Leaves before Floral Transition. Scientia Horticulturae, 102, 121-132. http://dx.doi.org/10.1016/j.scienta.2003.12.006

[5] Guo, W.J. and Lee, N. (2006) Effect of Leaf and Plant Age and Day/Night Temperature on Net $\mathrm{CO}_{2}$ Uptake in Phalaenopsis amabilis var. Formosa. Journal of the American Society for Horticultural Science, 131, 320-326.

[6] Tsai, W.T., Wang, Y.T. and Lin, H.L. (2008) Alternating Temperature Affects Spiking of a Hybrid Phalaenopsis. Acta Horticulturae, 766, 307-314. http://dx.doi.org/10.17660/ActaHortic.2008.766.40

[7] Wu, P.H., Liu, C.H., Tseng, K.M., Liu, Y.C., Chen, C.C., Yang, P.P., Huang, Y.X., Chen, W.H. and Wang, H.L. (2013) Low Irradiance Alters Carbon Metabolism and Delays Flower Stalk Development in Two Orchids. Biologia Plantarum, 54, 764-768. http://dx.doi.org/10.1007/s10535-013-0340-2

[8] Chen, W.H., Tseng, Y.C., Liu, Y.C., Chuo, C.M., Chen, P.T., Tseng, K.M., Yeh, Y.C., Ger, M.J. and Wang, H.L. (2008) Influence of Cool-Night on the Photosynthetic Efficiency and the Nonstructural Carbohydrate and Organic Acid Pools in Phalaenopsis aphrodite. Plant Cell Reports, 27, 1667-1675. http://dx.doi.org/10.1007/s00299-008-0591-0

[9] Liu, Y.C., Tseng, K.M., Chen, C.C., Tsai, Y.T., Liu, C.H., Chen, W.H. and Wang, H.L. (2013) Warm-Night Temperature Delays Spike Emergence and Alters Dawn-Dusk Changes in Carbon Pool Metabolism in the Stem and Leaves of Phalaenopsis aphrodite. Scientia Horticulturae, 161,198-203. http://dx.doi.org/10.1016/j.scienta.2013.06.046

[10] Liu, Y.C., Liu, C.H., Lin, Y.C., Lu, C.H., Chen, W.H. and Wang, H.L. (2015) Lowering Irradiance on the Photosyn- 
thetic Performance and Spiking of Phalaenopsis. Photosynthetica.

http://dx.doi.org/10.1007/s11099-016-0079-z

[11] Demotes-Mainard, S., Péron, T., Corot, A., Bertheloot, J., Le Gourrierec, J., Pelleschi-Travier, S., Crespel, L., Morel, P., Huché-Thélier, L., Boumaza, R., Vian, A., Guérin, V., Leduc, N. and Sakr, S. (2016) Plant Responses to Red and Far-Red Lights, Applications in Horticulture. Environmental and Experimental Botany, 121, 4-21. http://dx.doi.org/10.1016/j.envexpbot.2015.05.010

[12] Halliday, K.J., Salter, M.G., Thingnaes, E. and Whitelam, G.C. (2003) Phytochrome Control of Flowering Is Temperature Sensitive and Correlates with Expression of the Floral Integrator FT. The Plant Journal, 33, 875-885. http://dx.doi.org/10.1046/j.1365-313X.2003.01674.x

[13] Cober, E.R. and Voldeng, H.D. (2001) Low R:FR Light Quality Delays Flowering of E7E7 Soybean Lines. Crop Science, 41, 1823-1826. http://dx.doi.org/10.2135/cropsci2001.1823

[14] Haliapas, S., Yupsanis, T. A., Syros, T. D., Kofidis, G. and Economou, A. S. (2008) Petunia×hybrida during Transition to Flowering as Affected by Light Intensity and Quality Treatments. Acta Physiologiae Plantarum, 30, 807-815. http://dx.doi.org/10.1007/s11738-008-0185-z

[15] Takeda, F., Glenn, D.M. and Stutte, G.W. (2008) Red Light Affects Flowering under Long Days in a Short-Day Strawberry Cultivar. HortScience, 43, 2245-2247.

[16] Sawhney, R. (1997) Nature of Light Requirement for Flowering of Chenopodium rubrum L. (Ecotype 60 47’N). I. Pre-Induction Light Period. Planta, 133, 97-102. http://dx.doi.org/10.1007/BF00391904

[17] Zhao, J.J., Yang, Q.C. and Liu, W.K. (2014) Effects of LED Light Qualities on Growth and Photosynthetic Pigments of Atractylodes macrocephala. Acta Horticulturae, 1037, 849-853. http://dx.doi.org/10.17660/ActaHortic.2014.1037.113

[18] Lin, K.H., Huang, M.H., Huang, W.D., Hsu, M.H., Yang, Z.W. and Yang, C.M. (2013) The Effects of Red, Blue, and White Light-Emitting Diodes on the growth, Development, and Edible Quality of Hydroponically Grown Lettuce (Lactuca sativa L. var. capitata). Scientia Horticulturae, 150, 86-91. http://dx.doi.org/10.1016/j.scienta.2012.10.002

[19] Heo, J.W., Lee, C.W., Chakrabarty, D. and Paek, K.Y. (2002) Growth Responses of Marigold and Salvia Bedding Plants as Affected by Monochromic or Mixture Radiation Provided by a Light-Emitting Diode (LED). Plant Growth Regulation, 38, 225-230. http://dx.doi.org/10.1023/A:1021523832488

[20] Pu, G.B., Liu, S.Q. and Liu, L. (2005) Effects of Different Light Qualities on Growth and Physiological Characteristics of Tomato Seedlings. Acta Horticulturae Sinica, 32, 420-425.

[21] Wang, S., Chen, Q., Kong, Y. and Fan, S. (2007) Effect of Light Quality on the Growth and Photosynthetic Characteristics of Cucumber Cucumis sativus L. under Solar Greenhouse. Acta Horticulturae, 731, 243-249. http://dx.doi.org/10.17660/ActaHortic.2007.731.33

[22] Jiang, M.Y. and Pan, Y.Z. (2006) Effects of Light Quality on the Photosynthetic Characteristics and Growth of Poinsettia. Acta Horticulturae Sinica, 33, 338-343.

[23] Lokhande, S.D., Ogawa, K., Tanaka, A. and Hara, T. (2003) Effect of Temperature on Ascorbate Peroxidase Activity and Flowering of Arabidopsis Thaliana Ecotypes under Different Light Conditions. Journal of Plant Physiology, 160, 57-64. http://dx.doi.org/10.1078/0176-1617-00990

[24] Endo, M. and Ikusima, I. (1989) Diurnal Rhythm and Characteristics of Photosynthesis and Respiration in the Leaf and Root of a Phalaenopsis Plant. Plant and Cell Physiology, 30, 43-47.

[25] Pollet, B., Vanhaecke, L., Dambre, P., Lootens, P. and Steppe, K. (2011) Low Night Temperature Acclimation of Phalaenopsis. Plant Cell Reports, 30, 1125-1134. http://dx.doi.org/10.1007/s00299-011-1021-2

[26] Wu, P.H., Liu, C.H., Tseng, K.M., Liu, Y.C., Chen, C.C., Yang, P.P., Huang, Y.X., Chen, W.H. and Wang, H.L. (2013) Low Irradiance Alters Carbon Metabolism and Delays Flower Stalk Development in Two Orchids. Biologia Plantarum, 54, 764-768. http://dx.doi.org/10.1007/s10535-013-0340-2

[27] Lee, Y.I., Fang, W. and Chen, C.C. (2011) Histological Observation on the Growth of Potato Plantlet in Vitro under Six Different Led Light Qualities. Acta Horticulturae, 907, 393-395. http://dx.doi.org/10.17660/ActaHortic.2011.907.66

[28] Brazaityte, A., Ulinskaitè, R., Duchovskis, P., Samuolienė, G., Šikšnianienè, J.B., Jankauskienė, J., Šabajevienė, G., Baranauskis, K., Staniene, G., Tamulaitis, G., Bliznikas, Z. and Žukauskas, A. (2006) Optimization of Lighting Spectrum for Photosynthesis System and Productivity of Lettuce by Using Light-Emitting Diodes. Acta Horticulturae, 71, 183-188. http://dx.doi.org/10.17660/ActaHortic.2006.711.22

[29] Massa, G.D., Kim, H.H., Wheeler, R.M. and Mitchell, C.A. (2008) Plant Productivity in Response to LED Lighting. HortScience, 43, 1951-1956.

[30] Kurata, K., Matsuda, R., Sabeh, N., Giacomelli, G.A., Kubota, C., Sase, S., Ishii, M., Ikeguchi, A. and Yokoi, S. (2007) 
Light Quality in and between Tomato Plant Rows in a Greenhouse. Acta Horticulturae, 761, 227-234. http://dx.doi.org/10.17660/ActaHortic.2007.761.29

[31] Sanger, J.C., Smith, W.O., Edwards, J.L. and Cyr, K.L. (1988) Photosynthetic Efficiency and Phytochrome Photoequilibria Determination Using Spectral Data. Transactions of the American Society of Agricultural Engineers, 31, 1882-1889. http://dx.doi.org/10.13031/2013.30952

[32] Lichtenthaler, H.K. (1987) Chlorophylls and Carotenoids: Pigments of Photosynthetic Biomembranes. Methods in Enzymology, 148, 350-382. http://dx.doi.org/10.1016/0076-6879(87)48036-1

[33] Amasino, R.M. (1996) Control of Flowering Time in Plants. Current Opinion in Genetics and Development, 6, 480-487. http://dx.doi.org/10.1016/S0959-437X(96)80071-2

[34] Leite, C.A., Ito, R.M., Lee, G.T.S., Ganelevin, R. and Fagnani, M.A. (2008) Light Spectrum Management Using Colored Nets to Control the Growth and Blooming of Phalaenopsis. Acta Horticulturae, 770, 177-184. http://dx.doi.org/10.17660/ActaHortic.2008.770.20

[35] Dueck, T., Trouwborst, G., Hogewoning, S.W. and Meinen, E. (2016) Can a High Red: Far Red Ratio Replace Temperature-Induced Inflorescence Development in Phalaenopsis? Environmental and Experimental Botany, 121, 139-144. http://dx.doi.org/10.1016/j.envexpbot.2015.05.011

[36] Castillon, A., Shen, H. and Huq, E. (2007) Phytochrome Interacting Factors: Central Players in Phytochrome-Mediated Light Signaling Networks. Trends in Plant Science, 12, 514-521. http://dx.doi.org/10.1016/j.tplants.2007.10.001

[37] Toyomatsu, T., Kawaide, H., Inoue, Y. and Kamiya, Y. (1998) Phytochrome Regulates Gibberellin Biosynthesis during Germination of Photoblastic Lettuce Seeds. Plant Physiology, 118, 1517-1523. http://dx.doi.org/10.1104/pp.118.4.1517

[38] Ben-Tal, Y. and Erner, Y. (1999) Flowering Control by Artificial Gibberellins. Acta Horticulturae, 482, 21-26. http://dx.doi.org/10.17660/ActaHortic.1999.482.1

[39] Su, W.R., Chena, W.S., Koshioka, M., Mander, L.N., Hung, L.S., Chen, W.H., Fu, Y.M. and Huang, K.L. (2001) Changes in Gibberellin Levels in the Flowering Shoot of Phalaenopsis hybrida under High Temperature Conditions When Flower Development Is Blocked. Plant Physiology and Biochemistry, 39, 45-50. http://dx.doi.org/10.1016/S0981-9428(00)01218-3

[40] Blanchard, M.G. and Runkle, E.S. (2008) Benzyladenine Promotes Flowering in Doritaenopsis and Phalaenopsis Orchids. The Journal of Plant Growth Regulation, 27, 141-150. http://dx.doi.org/10.1007/s00344-008-9040-0

[41] Kamiya, Y. and Garcia-Martinez, J.L. (1999) Regulation of Gibberellin Biosynthesis by Light. Current Opinion in Plant Biology, 2, 398-403. http://dx.doi.org/10.1016/S1369-5266(99)00012-6

[42] Vandenbussche, F., Pierik, R., Millenaar, F.F., Voesenek, L.A.C.J. and Van Der Straeten, D. (2005) Reaching out of the Shade. Current Opinion in Plant Biology, 8, 462-468. http://dx.doi.org/10.1016/j.pbi.2005.07.007

[43] Blanchard, M.G. and Runkle, E.S. (2006) Temperature during the Day, but Not during the Night, Controls Flowering of Phalaenopsis Orchids. Journal of Experimental Botany, 57, 4043-4049. http://dx.doi.org/10.1093/jxb/erl176

[44] Paradiso, R. and De Pascale, S. (2014) Effects of Plant Size, Temperature, and Light Intensity on Flowering of Phalaenopsis Hybrids in Mediterranean Greenhouses. The Scientific World Journal, 2014, Article ID: 420807. http://dx.doi.org/10.1155/2014/420807

[45] Blanchard, M.G., Lopez, R., Runkle, E.S. and Wang, Y.T. (2007) Growing the Best Phalaenopsis. Orchids, 4, 266271.

[46] Wang, Y.T. (1995) Phalaenopsis Light Requirement during the Induction of Spiking. HortScience, 30, 59-61. 